Table 1. BReEding Systmus and Compatibiumt in Glyceria

\begin{tabular}{|c|c|c|c|c|c|c|c|c|c|c|c|c|c|c|c|c|}
\hline & \multicolumn{8}{|c|}{ G. fluitans } & \multicolumn{8}{|c|}{ G. plicata } \\
\hline & \multicolumn{2}{|c|}{ Selfed } & \multicolumn{2}{|c|}{$\begin{array}{c}\text { Open } \\
\text { pollinated* }\end{array}$} & \multicolumn{2}{|c|}{$\begin{array}{c}\text { Crosses } \\
\text { within } \\
\text { populations }\end{array}$} & \multicolumn{2}{|c|}{$\begin{array}{c}\text { Crosses } \\
\text { between } \\
\text { populations }\end{array}$} & \multicolumn{2}{|c|}{ Selfed } & \multicolumn{2}{|c|}{$\begin{array}{c}\text { Open } \\
\text { pollinated* }\end{array}$} & \multicolumn{2}{|c|}{$\begin{array}{c}\text { Crosses } \\
\text { within } \\
\text { populations }\end{array}$} & \multicolumn{2}{|c|}{$\begin{array}{c}\text { Crosses } \\
\text { between } \\
\text { populations }\end{array}$} \\
\hline & Heavy $\dagger$ & Light $\ddagger$ & Heavy & Light & Heavy & Light & Heavy & Light & Heavy & Light & Heavy & Light & Heavy & Light & Heavy & Light \\
\hline $\begin{array}{l}\text { Mean seed } \\
\text { set (per } \\
\text { cent) } \\
\text { Range (per } \\
\text { cent) }\end{array}$ & $\begin{array}{c}27 \\
8-58\end{array}$ & $\begin{array}{c}46 \\
13-67\end{array}$ & $\begin{array}{c}67 \\
65-71\end{array}$ & $\begin{array}{c}19 \\
6-23\end{array}$ & $\begin{array}{c}62 \\
51-75\end{array}$ & $\mid \begin{array}{c}10 \\
12-19\end{array}$ & $\begin{array}{r}1 \cdot 2 \\
0-9\end{array}$ & $\begin{array}{r}2 \cdot 5 \\
0-10\end{array}$ & $\begin{array}{c}81 \\
69-97\end{array}$ & $\begin{array}{c}6 \\
4-9\end{array}$ & $\begin{array}{c}84 \\
81-86\end{array}$ & $\begin{array}{c}4 \\
2-8\end{array}$ & $\begin{array}{c}76 \\
68-81\end{array}$ & $\mid \begin{array}{c}12 \\
7-17\end{array}$ & $\begin{array}{c}75 \\
70-81\end{array}$ & $\begin{array}{c}9 \\
6-12\end{array}$ \\
\hline $\begin{array}{l}\text { Mean seed } \\
\text { viability } \\
\text { (per cent) } \\
\text { (Heavy } \\
\text { light) } \\
\text { Range (per } \\
\text { cent) }\end{array}$ & \multicolumn{2}{|c|}{$\begin{array}{c}54 \\
2-90\end{array}$} & \multicolumn{2}{|c|}{$\begin{array}{c}88 \\
87-90\end{array}$} & \multicolumn{2}{|c|}{$\begin{array}{c}54 \\
50-58\end{array}$} & \multicolumn{2}{|c|}{$\begin{array}{c}1 \cdot 7 \\
0-21\end{array}$} & \multicolumn{2}{|c|}{$\begin{array}{c}92 \\
82-100\end{array}$} & \multicolumn{2}{|c|}{$\begin{array}{c}83 \\
65-97\end{array}$} & \multicolumn{2}{|c|}{$\begin{array}{c}95 \\
90-100\end{array}$} & \multicolumn{2}{|c|}{$\begin{array}{c}86 \\
80-95\end{array}$} \\
\hline
\end{tabular}

* Data from two populations only. † Heavy seed : graing of full size. $\ddagger$ Light seed : grains less than two-thirds full size.

Tests were carried out to determine self- and crosscompatibility within and between populations. Hand emasculation followed by 'automatic pollination' was adopted in making crosses ${ }^{5}$. Compatibility was assessed on the basis of seed-set and viability.

A varying degree of self-incompatibility from plant to plant is characteristic of outbreeding grasses ${ }^{B}$. Comparing the results obtained from selfing with those from uncontrolled outcrossing (Table 1), it can be seen that $G$. fuitans plants are to various extents self-incompatible. This is shown by the low percentage of heavy seed obtained on selfing. Seed viability is related to degree of self-incompatibility, germination being poorest in the most self-sterile plants. G. plicata plants are by contrast highly selfcompatible.

Observations were made of behaviour at anthesis. In $G$. fuitans the florets opened briefly and the large pendulous anthers were fully exserted on long filaments prior to dehiscence, which occurred before the stigmas were fully expanded. The florets of $G$. plicata stood open, and the small anthers were borne out on rather stiff filaments, dehiscing above the fully expanded stigmas. These facts strongly suggest that G. fluitans is a predominantly outbreeding species, and $G$. plicata generally inbreeding. In the latter species, though pollination is required for seed setting, apomixis may occur to some extent.

The results of controlled hybridization indicate that, in G. plicata, plants derived both from the same and different populations are highly cross-compatible. By contrast, in $G$. fluitans the results of intra- and inter-population crosses differ markedly.

Seed set in intra-population crosses (62 per cent heavy seed) about equalled that obtained on outcrossing (67 per cent heavy seed); there was, how. ever, some reduction in virbility, 54 per cent as against 88 per cent on outcrossing.

In inter-population crosses, few or no seeds were set $(1 \cdot 2$ per cent heavy seed) and the viability of these was poor ( $1 \cdot 7$ per cent).

This suggests that a degree of incompatibility exists between parts of the G. fluitans species-population, sufficient to limit or prevent gene-exchange. In both species the local populations sampled were distinct morphologically and perhaps equally well isolated from the micro-evolutionary point of view. Incompatibility occurs in G. fluitans, but is apparently ebsent from $G$. plicata, and this is probably related to the breeding systems of these species?

This work forms part of a biosystematic study of the British species of Sect. Euglyceria carried out at the University College of Leicester, the results of which will be given in full elsewhere.

Grass Breeding Section,

MARTIN Borrill

Welsh Plant Breeding Station, Aberystwyth.

Nov. 29.

${ }^{1}$ Clausen, J., "Stages in the Evolution of Plant Species" (New York,

' Gregor, J. W., New Phyt., 35, 327 (1936).

${ }^{3}$ Church, G. L., Amer. J. Bot., 36, 155 (1949).

s Fitzpatrick, J. M., New Phyt., 45, 137 (1946).

5 Jenkin, T. J., Bull. Welsh Plant Breed. Stat., Ser. H., No. 2,1 (1924).

-Jenkin, T. J., Bull. Welsh Plant Breed. Stat., Ser. H., No. 12, 100 (1931).

'Baker, H. G., Evolution, 6, 61 (1952).

\section{Arginase in Elasmobranch Muscle}

Hunter and Dauphine ${ }^{1}$ demonstrated the presence of arginase in the voluntary muscle of the dogfish (Squalus sucklii) and also possibly in the muscle of the herring. In the course of another investigation, it has now been observed that this is not true of other elasmobranchs, since no arginase activity was found in the skeletal muscle of the common skate (Raja batis), thornback skate ( $R$. clavata) or cuckoo ray $(R$. circularis) using the conditions of determination of Van Slyke and Archibald ${ }^{2}$ with the colorimetric procedure of Engel and Engel ${ }^{3}$. Activity was, however, observed in both the ordinary 'white' skeletal muscle $\left(0 \cdot 3\right.$ arginase units ${ }^{2} / \mathrm{mgm}$. extract nitrogen) and 'red' lateral-band muscle $(0 \cdot 75$ arginase units/mgm. extract nitrogen) of the lesser-spotted dogfish (Scyliorhinus caniculus) (cf. the observations of Matsuura et al." on several non-elasmobranch species of fish).

It seems that for the rays, at least, the extrahepatic regulation of urea which appears to occur in elasmobranchs cannot take place in the muscle, even though this tissue is rich in urea.

Torry Research Station

J. J. CONNELL

(Food Investigation Organization,

Department of Scientific and Industrial Research), Aberdeen.

Dec. 2.

1 Hunter, A., and Dauphinee, J. A., Proc. Roy. Soc., B, 97, 227 (1924).

2 Van Slyke, D. D., and Archibald, R. M., J. Biol. Chem., 165, 293 (1946).

3 Engel, M. G., and Engel, F. L., J. Biol. Chem., 167, 535 (1946).

4 Matsuura, F., Baba, H. J., and Mori, T., Bull. Jap. Soc. Sci. Fish., 19,893 (1953). 